\title{
EFEKTIVITAS PENGGUNAAN MODEL PEMBELAJARAN EXAMPLES NON EXAMPLES UNTUK MENINGKATKAN KEMAMPUAN BERPIKIR KRITIS SISWA DALAM PEMBELAJARAN MATEMATIKA PADA SISWA KELAS X DI SMK SWASTA AZ-ZAHRA SONOMARTANI T.P. 2019/2020
}

\section{THE EFFECTIVENESS OF USING THE NON-EXAMPLES EXAMPLES LEARNING MODEL TO IMPROVE STUDENT'S CRITICAL THINKING ABILITY IN LEARNING MATHEMATICS IN CLASS X STUDENTS IN SMK SWASTA AZ-ZAHRA SONOMARTANI T.P. 2019/2020}

\author{
SRI ENDANGSIH ${ }^{1}$, INDAH FITRIA RAHMA ${ }^{2}$ \\ ${ }^{1}$ Guru SMK Az-Zahra Sonomartani, \\ Jl. Sonomartani, Kualuh Hulu, Kabupaten Labuhanbatu Utara : email: sriendangsih1981@gmail.com \\ ${ }^{2}$ FKIP Universitas Labuhanbatu \\ 2JIn. Sisingamangaraja, Km 4,5 Aek Tapa Rantauprapat: email:indahfitria286@gmail.com
}

\begin{abstract}
Abstrak
Tujuan penelitian ini adalah untuk mengetahui model pembelajaran Examples Non Examples dapat meningkatkan kemampuan berfikir kritis siswa dalam pembelajaran matematika, serta efektifitas pengguanaan model pembelajaran Examples Non Examples dalam pembelajaran matematika. Jenis penelitian ini adalah Quasi eksperimen serta dilakukan di SMK Az- Zahra sonomartani dengan jumlah siswa 33 orang. Pengumpulan data penelitian ini menggunakan tes, angket dan dokumentasi. Teknik analisis data menggunakan deskriptif data, dengan uji t serta uji gain. Hasil penelitian ini diperoleh bahwa: (1) dengan menerapkan model pembelajaran Examples Non Examples dapat meningkatkan kemapuan berfikir kritis siswa memiliki nilai rata-rata lebih tinggi dibandingkan dengan nilai rata-rata siswa sebelum menggunakan model pembelajaran tersebut yaitu 57,30 dibandingkan 83,55 . Nilai tertinggi yang diperoleh siswa sebelum menggunakan model pembelajaran examples non examples 75 setelah menggunakan model pembelajaran examples non examples 95. Berdasarkan hasil uji t dengan menggunakan SPSS 17.30 diketahui nilai signifikan $0,0510>\alpha=0,05$ sehingga Ha diterima. Berarti terdapat pengaruh model pembelajaran examples non examples terhadap kemampuan berpikir kritis siswa. (2) Hasil uji N-Gain Score menunjukan bahwa nilai rata-rata N-gain score untuk metoda pembelajaran Examples Non Examples sebesar 62,6187 atau 62,62\% dengan kategori cukup efektif. Simpulan dengan penggunaan model pembelajaran Examples Non Examples cukup efektif dalam meningkatkan berfikir kritis siswa semakin tinggi sesuaian dengan kegiatan ekstrakurikuler dengan minat maka semakin tinggi kreativitas siswa dengan nilai $r_{x y 1}=0,546$ (2) Semakin tinggi kesesuaian kegiatan ekstrakurikuler dengan minat maka semakin tinggi kemandirian dengan nilai $r_{x y 2}=0,599$. (3) Semakin tinggi kesesuaian kegiatan ekstrakurikuler dengan minat maka semakin tinggi kesiapan kerja siswa dengan nilai $r_{x y 3}=0,574$.
\end{abstract}

Kata kunci : Efektivitas Examples Non Examples, Kemampuan Berpkir Kritis

\begin{abstract}
The purpose of this study was to determine the Examples Non Examples learning model can improve students' critical thinking skills in learning mathematics, as well as the effectiveness of using Examples Non Examples learning models in mathematics learning. This type of research is a Quasi-experimental and conducted at SMK Az-Zahra Sonomartani with 33 students. This research data collection using tests, questionnaires and documentation. The data analysis technique used descriptive data, with t test and gain test. The results of this study indicate that: (1) by applying the Examples Non Examples learning model it can improve the critical thinking skills of students who have a higher average score than the students' average score before using the learning model, namely 57.30 compared to 83.55 . The highest score obtained by students before using the examples non examples learning model 75 after using the examples non examples learning model 95. Based on the results of the t test using SPSS 17.30 , it is known that the significant value is $0.0510>\alpha=0.05$ so that $\mathrm{Ha}$ is accepted. This means that there is an effect of the examples non examples learning model on students' critical thinking skills. (2) The results of the N-Gain Score test show that the average N-gain score for the Examples Non Examples learning method is 62.6187 or $62.62 \%$ with the category quite effective. In conclusion, the use of the Examples Non Examples learning model is quite effective in improving students' critical thinking, the higher the suitability of extracurricular activities with interest, the higher the student's creativity with a value of rxy1 $=0.546$ (2) The higher the suitability of extracurricular activities with interest, the higher the independence with the value of rxy2 $=0.599$. (3) The higher the suitability of extracurricular activities with interests, the higher the students' work readiness with a value of rxy3 $=0.574$.
\end{abstract}

Key Words : Effectiveness of Examples Non Examples, Critical Thinking Ability 


\section{Pendahuluan}

Pendidikan merupakan kebutuhan sepanjang hayat. Setiap manusia membutuhkan pendidikan sampai kapan pun dan dimana pun seseorang itu berada. Pendidikan sangat penting bagi kehidupan kita, sebab tanpa pendidikan manusia akan sulit berkembang dan akan terbelakang. Dengan demikian pendidikan harus betulbetul diarahkan untuk menghasilkan manusia yang berkualitas dan mampu bersaing, disamping memiliki budipekerti yang luhur dan moral yang baik [1]. Oleh karena itu, perlu peningkatan terhadap kualitas pendidikan itu sendiri terutama dalam proses belajar mengajar [6]. Dalam proses pembelajaran, nampaknya belum banyak guru yang menciptakan kondisi dan situasi yang memungkinkan siswa untuk melakukan proses berpikir kritis. Hal ini terlihat dari kegiatan guru dan siswa pada saat kegiatan belajar-mengajar. Guru menjelaskan apa-apa yang telah disiapkan dan memberikan soal latihan yang bersifat rutin dan prosedural. Siswa hanya mencatat atau menyalin dan cenderung menghafal rumus-rumus atau aturan-aturan matematika dengan tanpa makna dan pengertian [3].

Strategi yang paling sering dilakukan guru untuk mengaktifkan siswa ialah melibatkan siswa dalam diskusi dengan seluruh kelas, yaitu dari guru ke siswa dan dari siswa ke guru [7]. Berdasarkan kondisi kegiatan pembelajaran tersebut, siswa tidak terlatih berpikir kritis. Padahal salah satu tujuan jangka panjang pembelajaran matematika harusnya mengembangkan pemikiran yang kritis [8].

Hasil wawancara saya dengan guru matematika di SMK Az-Zahra Sonomartani, menurut beliau pendidikan matematika telah menjadi pelajaran yang kurang digemari oleh sebagian besar siswa. Salah satu penyebabnya adalah kurangnya minat dan keaktifan dalam diri siswa pada waktu menerima pembelajaran sehingga mengakibatkan siswa tidak dapat berfikir kritis terhadap materi pelajaran. Sebagian besar siswa berpendapat Pendidikan matematika adalah pelajaran tersulit yang mereka jumpai dari pertama mengenyam pendidikan di SD.

Agar tercapainya pembelajaran yang efektif, guru diharapkan mampu menciptakan proses pembelajaran yang menyenangkan bagi siswa [10]. Selain itu, guru juga harus bisa membangkitkan perhatian dan keaktifan siswa. Keaktifan siswa akan mempengaruhi keberhasilan belajarnya. Bila keaktifan belajar yang dimiliki siswa sangat baik maka akan diperoleh hasil belajar yang optimal [5]. Keaktifan siswa dalam pembelajaran matematika dipengaruhi oleh penggunaan model pembelajaran. Model pembelajaran merupakan suatu perencanaan yang dilakukan guru untuk membuat siswa lebih aktif terlibat dalam kegiatan pembelajaran. Model pembelajaran yang efektif adalah model pembelajaran yang menekankan pada keaktifan siswa dalam proses belajar.

Dengan pemilihan model pembelajaran yang tepat maka akan terjadi proses belajar mengajar yang efektif sehingga hasil belajar menjadi meningkat. Ada banyak model pembelajaran yang dapat digunakan dalam pembelajaran. Salah satu model pembelajaran yang diprediksi akan mampu secara efektif meningkatkan berfikir kritis siswa adalah model pembelajaran Examples Non Examples [8]. Model pembelajaran Examples Non Examples merupakan model pembelajaran yang menggunakan gambar sebagai media untuk menyampaikan materi pelajaran. Model pembelajaran ini bertujuan mendorong siswa untuk belajar berpikir kritis dengan memecahkan permasalahan-permasalahan yang termuat dalam contoh-contoh gambar yang disajikan. Berdasarkan uraian diatas penelitian melihat Efektivitas Penggunaan Model Pembelajaran Examples Non Examples Untuk Meningkatkan kemampuan Berfikir Kritis Siswa Dalam Pembelajaran Matematika pada Siswa Kelas X di SMK Az-Zahra Sonomartani T.P 2019/2020.

\section{Metode Penelitian}

Metode penelitian yang yang di gunakan dalam penelitian ini adalah metode eksperimen atau Quasy eksperimen yaitu, penelitian yang mendekati percobaan sungguhan dimana tidak mungkin mengadak [2]. Desain yang di gunakan adalah One Group- Pretest-Posttest. Dalam kegiatan uji coba tidak menggunakan kelompok control. Desain ini di lakukan dengan membandingkan hasil pretest dan posttest pada kelompok kelas eksperimen Populasi dalam penelitian ini adalah seluruh siswa Kelas X SMK Swasta Az- zahra Sonomartani Tahun Pelajaran 2019/2020 yang berjumlah 89 siswa yang terdiri atas:

Tabel 1. Populasi Penelitian

\begin{tabular}{|c|c|c|}
\hline No & Kelas & Jumlah \\
\hline 1 & X Akuntansi & 33 siswa \\
\hline 2 & X TBSM & 22 siswa \\
\hline 3 & X TKJ & 34 siswa \\
\hline \multicolumn{2}{|c|}{ Total siswa } & 89 siswa \\
\hline
\end{tabular}


Sampel adalah bagian dari populasi yang di anggap mewakili sebagai sumber data. Dalam penelitian ini, yang menjadi sampelnya yaitu kelas X Akuntansi yang terdiri dari 33 siswa sebagai kelas eksperimen. Teknik sampling yang akan digunakan dalam pengambilan kelas eksperimen adalah propability sampling dengan cluster random sampling. Teknik pengambilan sampel dari populasi dilakukan secara acak tanpa memperhatikan strata yang ada dalam populasi itu [4]. Pengundian dilakukan dengan memberikan nomor urut pada setiap kelas kemudian diambil secara acak [9]. Demikian didapat sampel yang terambil yaitu kelas $X$ Akuntansi dengan jumlah 33 siswa sebagai kelas eksperimen yang menjadi sampel dalam penelitian.

\section{Hasil Penelitian dan Pembahasan}

\section{Hasil Penelitian}

Pengujian tes kemampuan berfikir kritis siswa dalam penelitian ini dilakukan di kelas X Smk Az-Zahra Sonomartani Tahun ajaran 2019/2020. Dalam penelitian ini, peneliti menggunakan satu kelas sebagai kelas sampel, yaitu kelas X-Akuntansi sebagai kelas eksperimen dengan jumlah siswa 33 siswa. Untuk mengetahui kemampuan berfikir kritis siswa, data yang telah dihitung akan dianalisis secara deskriptif. Secara ringkas hasil penelitian dapat dideskripsikan seperti terlihat pada tabel di bawah ini :

Tabel 2. Perbedaan Hasil Belajar pre test dan post test

\begin{tabular}{|c|c|c|}
\hline Sumber Statistik & Pre Test & Post test \\
\hline \multirow{4}{*}{ Pembelajaran Examples Non Examples } & $\mathrm{n}=33$ & $\mathrm{n}=33$ \\
\cline { 2 - 3 } & $\sum \mathrm{X}=1891$ & $\sum \mathrm{X}=2755$ \\
\cline { 2 - 3 } & $\sum \mathrm{X}^{2}=3575881$ & $\sum \mathrm{X}^{2}=7590025$ \\
\cline { 2 - 3 } & $\mathrm{SD}=8.160$ & $\mathrm{SD}=6.088$ \\
\cline { 2 - 3 } & $\mathrm{Var}=66.593$ & $\mathrm{Var}=37.068$ \\
\cline { 2 - 3 } & Mean $=5730$ & Mean $=8348$ \\
\hline
\end{tabular}

Deskripsi masing-masing tes dapat diuraikan berdasarkan hasil analisis tendensi sentral seperti terlihat pada rangkuman hasil sebagai berikut:

Berdasarkan data yang diperoleh dari hasil pre-test untuk mengukur kemampuan berfikir kritis siswa yang belum dilakukan dengan pembelajaran Examples Non Examples, diperoleh data distribusi frekuensi pada lampiran. Dari perhitungan tersebut diperoleh nilai rata-rata hitung (mean) sebesar 57,30 dan standar deviasi $(S D)=8.160$.

Dari data tersebut dapat diketahui bahwa kemampuan berfikir kritis siswa yang dilakukan sebelum pembelajaran Examples Non Examples. Diperoleh data distribusi frekuensi pada lampiran 20 memperoleh nilai rata-rata (mean) siswa sebesar 57,30 dan standar deviasi (SD) sebesar 8.160 serta memiliki nilai yang sangat beragam atau berbeda antara siswa yang satu dengan siswa yang lainnya, karena dapat kita lihat bahwa nilai varians semua dalam kategori sedang. Secara kuantitatif dapat dilihat pada tabel berikut ini :

Tabel 3. Distribusi Frekuensi Pretest

\begin{tabular}{|l|l|l|l|}
\hline Kelas & Interval Kelas & $\mathrm{F}$ & Fr \\
\hline 1 & $45-50$ & 12 & $36.4 \%$ \\
\hline 2 & $50-55$ & 1 & $3.0 \%$ \\
\hline 3 & $55-60$ & 15 & $45.5 \%$ \\
\hline 4 & $60-65$ & 1 & $3.0 \%$ \\
\hline 5 & $65-70$ & 0 & $0 \%$ \\
\hline 6 & $70-75$ & 4 & $12.1 \%$ \\
\hline Jumlah & 33 & $100 \%$ \\
\hline
\end{tabular}

Tabel 4. Kategori Penilaian

\begin{tabular}{|l|l|l|l|l|}
\hline No & Ketentuan & $\begin{array}{l}\text { Jumlah } \\
\text { Siswa }\end{array}$ & Presentase & $\begin{array}{l}\text { Kategori } \\
\text { Penilaian }\end{array}$ \\
\hline 1 & $>76.63$ & 0 & $0 \%$ & Tinggi \\
\hline 2 & 47.69 s.d 76.63 & 33 & $100 \%$ & Sedang \\
\hline 3 & $<47.69$ & 0 & $0 \%$ & Rendah \\
\hline
\end{tabular}


Dari tabel di atas dapat diketahui bahwa kemampuan berfikir kritis siswa yang dilakukan sebelum pembelajaran Examples Non Examples diperoleh: Jumlah siswa yang memiliki nilai kategori sedang sebanyak 33 orang atau sebesar $100 \%$, hal ini berarti siswa belum sepenuhnya dalam berkemampuan berfikir kritis. Siswa masih mampu mengidentifikasi salah satu dari yang diketahui atau ditanyakan, kemudian dalam menguraikan langkah-langkah penyelesaian atau rumus, siswa dapat menuliskannya tetapi masih terdapat beberapa kesalahan dan hanya berfokus pada jawaban akhir yang mereka anggap benar serta mereka menuliskan penjelasan dengan benar, namun masih terdapat keterangan-keterangan atau kesimpulan akhir yang tidak sesuai. Secara keseluruhan diperoleh nilai rata-rata (Mean) $=57,12$ maka dapat disimpulkan kemampuan berfikir kritis siswa yang dilakukan sebelum pembelajaran Examples Non Examples dapat dikategorikan sedang, yakni secara umum siswa masih mampu memahami masalah secara sebagian, artinya siswa dapat menuliskan apa yang diketahui atau yang ditanyakan secara benar, dan siswa hanya menuliskan jawaban akhir saja dan tidak menguraikan langkah penyelesaian serta penjelasan dengan lengkap atau tepat karena masih terdapat beberapa kesalahan dalam penjelasan atau perhitungan.

Berdasarkan data yang diperoleh dari hasil post-test untuk mengukur kemampuan berfikir kritis siswa yang dilakukan setelah pembelajaran Examples Non Examples, diperoleh data distribusi frekuensi pada lampiran 11. Dari perhitungan tersebut diperoleh nilai rata-rata hitung (mean) sebesar $=83,55$, dan standar deviasi $(S D)=5.321$

Dari data tersebut dapat diketahui bahwa kemampuan berfikir kritis siswa yang dilakukan setelah pembelajaran Examples Non Examples, memperoleh nilai rata-rata (mean) siswa sebesar 83,55 dan standar deviasi (SD) sebesar 5.321 serta memiliki nilai yang sangat beragam atau berbeda antara siswa yang satu dengan siswa yang lainnya, karena dapat kita lihat bahwa nilai tertinggi yakni 95. Secara kuantitatif dapat dilihat pada tabel berikut ini :

Tabel 5. Distribusi Frekuensi

\begin{tabular}{|c|l|c|c|}
\hline Kelas & Interval Kelas & $\mathrm{F}$ & $\mathrm{Fr}$ \\
\hline 1 & $78-81$ & 17 & $51.5 \%$ \\
\hline 2 & $81-84$ & 0 & $0 \%$ \\
\hline 3 & $84-87$ & 7 & $21.2 \%$ \\
\hline 4 & $87-90$ & 3 & $9.1 \%$ \\
\hline 5 & $90-93$ & 0 & $0 \%$ \\
\hline 6 & $93-95$ & 6 & $18.2 \%$ \\
\hline Jumlah & 33 & $100 \%$ \\
\hline
\end{tabular}

Tabel 6. Kategori Penilaian

\begin{tabular}{|c|l|l|l|l|}
\hline No & Ketentuan & $\begin{array}{l}\text { Jumlah } \\
\text { Siswa }\end{array}$ & Presentase & $\begin{array}{l}\text { Kategori } \\
\text { Penilaian }\end{array}$ \\
\hline 1 & $>80.99$ & 6 & $18,2 \%$ & Tinggi \\
\hline 2 & 54.68 s.d 80.99 & 27 & $81.8 \%$ & Sedang \\
\hline 3 & $<54.68$ & 0 & $0 \%$ & Rendah \\
\hline
\end{tabular}

Dari tabel di atas dapat diketahui bahwa kemampuan berfikir kritis siswa yang dilakukan setelah pembelajaran Examples Non Exampless, diperoleh: (1) Jumlah siswa yang memiliki nilai kategori tinggi sebanyak 6 orang atau sebesar $18,2 \%$. Dari hasil tersebut berarti siswa dapat memahami masalah pada tes kemampuan berfikir kritis yang dimana siswa mampu menyelesaikan soal dengan baik, yaitu siswa menuliskan apa diketahui dan ditanya dengan benar, kemudian siswa juga dapat menuliskan langkah penyelesaian atau rumus dan jawaban dengan benar. (2) Jumlah siswa yang memiliki nilai kategori sedang sebanyak 27 orang atau sebesar $81,8 \%$, hal ini berarti siswa belum sepenuhnya dalam memahami masalah. Siswa masih belum mampu mengidentifikasi salah satu dari yang diketahui atau ditanyakan, kemudian dalam menguraikan langkah-langkah penyelesaian atau rumus, siswa dapat menuliskannya tetapi masih terdapat beberapa kesalahan dan hanya berfokus pada jawaban akhir yang mereka anggap benar.

\section{Uji Normalitas Data}

Uji normalitas dilakukan untuk mengetahui normal atau tidaknya sebaran data yang akan dianalisis. Analisis data normalitas menggunakan bantuan SPSS 17.0 for windows, dengan nilai alpha yang ditetapkan sebesar $5 \%(0,05)$.

Langkah-langkah dalam uji normalitas yaitu Analyze-non parametric test- One Sampel KS-masukkan variabel pada jendela variabel-klik normal pada test distribution lalu klik ok.

Uji normalitas dilakukan dengan metode Kolmogorov Smirnov Z. Menurut Priyatno, D (2010: 71) suatu data dikatakan berdistribusi normal jika memiliki signifikansi $>0,05$, sebaliknya suatu data dikatakan tidak 
Hal : $85-92$

berdistribusi normal jika memiliki signifikansi $<0,05$. Hasil uji normalitas data Pre test dan post test dapat dilihat pada Tabel 7.

Tabel 7. Hasil uji Normalitas data pre test dan post test kemampuan berfikir kritis siswa

Tests of Normality

\begin{tabular}{|ll|r|r|}
\hline & & PRITEST & POSTEST \\
\hline \multirow{3}{*}{ Normal Parameters ${ }^{\mathrm{a}, \mathrm{b}}$} & $\mathrm{N}$ & 33 & 33 \\
& Mean & 57.30 & 83.48 \\
& Std. Deviation & 8.160 & 8.775 \\
& Absolute & .219 & .236 \\
& Positive & .219 & .170 \\
& Negative & -.125 & -.236 \\
& Kolmogorov-Smirnov Z & 1.258 & 1.354 \\
& Asymp. Sig. (2-tailed) & .084 & .051 \\
\hline
\end{tabular}

Dari Tabel data pre test dan data post test mempunyai nilai signifikan 0,051 untuk mengetahui apakah sampel yang digunakan dalam penelitian berasal dari populasi yang homogen atau dapat mewakili populasi yang lainnya. Untuk pengujian homogenitas digunakan uji kesamaan kedua varians yaitu uji data pre test dan post test pada kedua sampel.

\section{Uji Homogenitas}

Langkah-langkah dalam uji homogenitas yaitu Analyze-compare means- One way anova-masukkan isi di kotak kiri ke indenfenden dan dependen - lalu klik options centreng Homogenelity of variance klik continue lalu klik Ok. Hasil uji homogenitas menggunakan SPSS statistic 17.0 for windows dapat dilihat pada Tabel 8.

Tabel 8. Hasil Uji Homogenitas pre test dan post test Kemampuan berfikir kritis siswa

\section{Test of Homogeneity of Variances}

HASILBELAJAR

\begin{tabular}{|c|c|c|c|}
\hline Levene Statistic & df1 & df2 & Sig. \\
\hline .002 & 1 & 64 & .967 \\
\hline
\end{tabular}

Uji homogenitas data pre test dan data post test di atas didapat nilai signifikan sebesar 0,967, karena nilai signifikan lebih besar dari $0,05(0,967>0,05)$ maka dapat dikatakan data pre test dan data post test kemampuan berfikir kritis siswa homogen.

1. Hipotesis pertama

Pada bagian diatas telah dilakukan pengolahan data, maka selanjutnya adalah pengujian hipotesis. Pengujian hipotesis bertujuan untuk memberikan jawaban yang dikemukakan peneliti apakah dapat diterima atau ditolaknya hipotesis yang diajukan, peneliti menggunakan Aplikasi SPSS Statistic versi 17.0.

Langkah-langkah dalam uji hipotestis t-test yaitu Analyze-compare means- indenfendent simple t-test masukkan isi di kotak kiri ke kanan dengan hasil belajar di tabel test variabel dan yang berkode di tabel grouping - lalu di grouping klik group $1=1$, dan group $2=2$ - lalu klik Ok. Hasil uji t-test menggunakan SPSS 17.0 dapat dilihat pada Tabel dibawah ini yaitu:

Berdasarkan hasil hipotesis diketahui nilai signifikansi (2-tailed) $=0,000<\alpha=0,05$ sehingga $\mathrm{HO}$ diterima

Dan H1 di tolak. Hal tersebut berarti terdapat peningkatan kemampuan berfikir kritis siswa dengan model pembelajaran examples non examples di kelas X SMK Az -Zahra Sonomartani.

Terdapat Pengaruh Model pembelajaran Examples Non Examples terhadap kemampuan berfikir kritis siswa di kelas X SMK Az -Zahra Sonomartani.

Dalam penelitian one group pretest posttest (eksperimen design), Uji N- Gain Score dapat di gunakan ketika ada perbedaan yang signifikan antara rata-rata nilai pretest dan posttest melalui Uji Paired sample T Test. N-Gain Score di gunakan untuk mengetahui apakah penggunaan metode tertentu dapat di katakana efektif atau tidak. 
Table 10. Hasil perhitungan N-Gain Score Descriptives

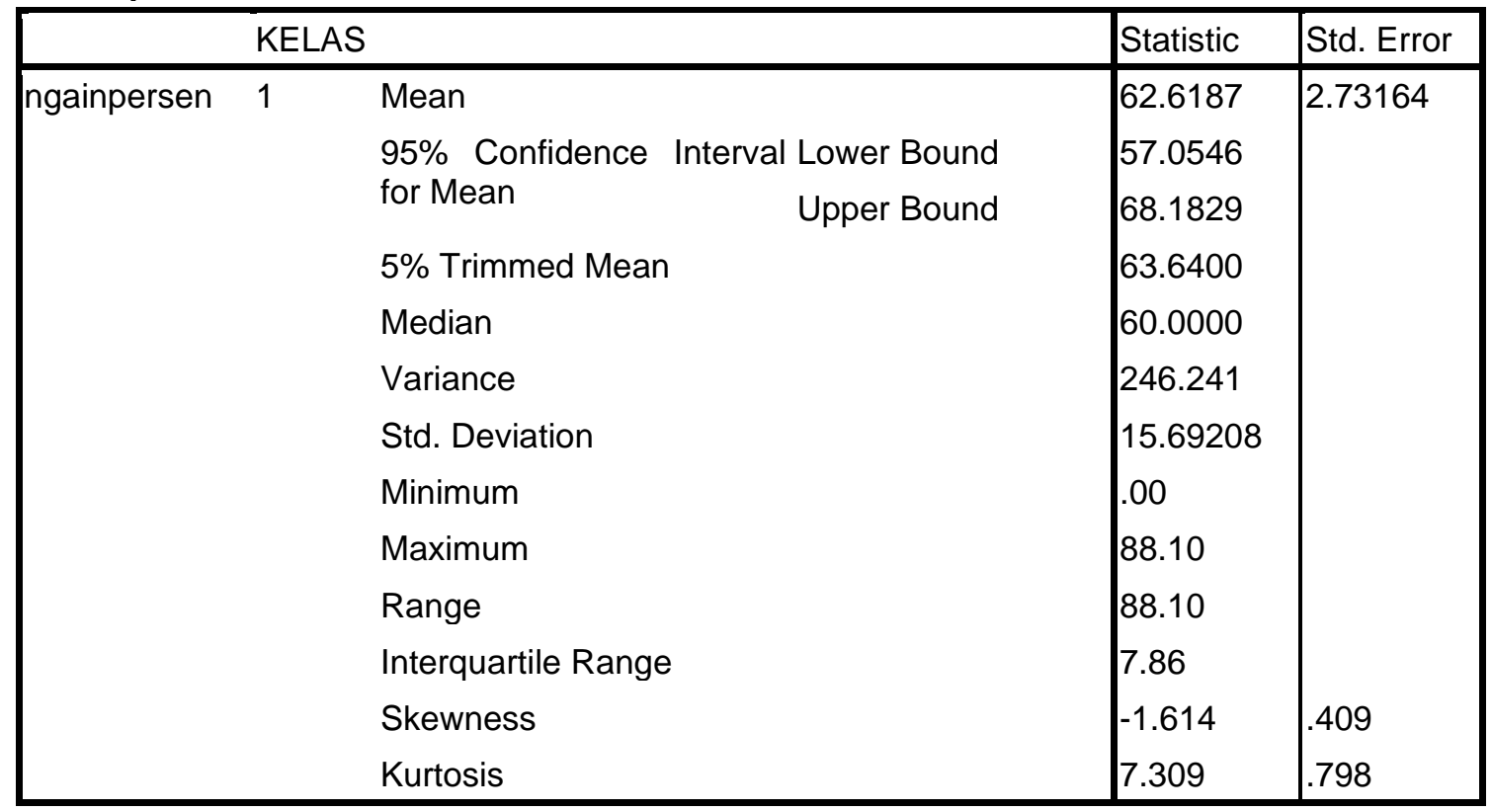

dapat di simpulkan yaitu

1. Dari hasil perhitungan uji N-Gain Score tersebut, menunjukan bahwa nilai rata-rata N-gain score untuk metoda pembelajaran Examples Non Examples sebesar 62,6187 atau 62,61\% termasuk dalam kategori cukup efektif

2. Maka dapat di simpulkan bahwa penggunaan model pembelajaran Examples Non Examples cukup efektif dalam meningkatkan berfikir kritis siswa kelas $X$ Akuntansi di SMK Swasta Az-Zahra Sonomartani.

\section{Pembahasan Hasil Penelitian}

Penelitian ini dilaksanakan di SMK Swasta Az - Zahra Sonomartani Jln.Kihajar Dewantara, yang melibatkan satu kelas yaitu kelas eksperimen dimana kelas X Akuntasi yang berjumlah 33 siswa. Pembelajaran yang diberikan pada kelas eksperimen menggunakan pembelajaran examples Non Examples. Pada bagian ini diuraikan deskripsi dan interpretasi data hasil penelitian.

sebagai kelas eksperimen dan 33 siswa diambil sebagai sampel, yang kemudian diajarkan dengan menggunakan model pembelajaran Examples Non Examples. Penelitian ini bertujuan untuk mengetahui apakah model pembelajaran Examples Non Examples dapat meningkatkan kemampuan berfikirkritis siswa dalam pembelajaran matematika dan keefektifan pembelajaran matematika dikelas X SMK Swasta Az-Zahra Sonomartani yang menggunakan Pendekatan Examples Non Examples. Penelitian ini dilakukan sebanyak 3 kali pertemuan pada kelas eksperimen. Pertemuan pertama pemberian pre-test, kemudian pertemuan selanjutnya digunakan untuk kegiatan pembelajaran dan pertemuan terakhir pemberian post-test serta pengisian angket sesudah perlakuan. Deskripsi dan interpretasi dilakukan terhadap kemampuan berfikir kritis siswa yang dilakukan sebelum (pre-test) dan sesudah (post-test) pembelajaran Examples Non Examples. Sesuai dengan data yang diperoleh, nilai rata-rata pre test dan post test kemampuan berfikir kritis siswa kelas eksperimen memiliki kondisi yang berbeda. nilai rata-rata pre test kemampuan berfikir kritis siswa kelas eksperimen 57,30 dan post-test 84,45.

Dapat disimpulkan bahwa antara nilai rata-rata pre-test dan post-test kemampuan berfikir kritis siswa kelas eksperimen sebelum dan sesudah pembelajaran Examples Non Examples jauh berbeda. Di karenakan nilai pretest lebih rendah di banding nilai posttest, dengan demikian dapat disimpulkan bahwa pembelajaran Examples Non Examples berpengaruh terhadap kemampuan berfiir kritis siswa. Hal tersebut terlihat pada kemampuan siswa saat diberlakuannya model pembelajaran Examples Non Examples.

Selama proses pembelajaran pada materi fungsi sub Relasi dan fungsi dengan pembelajaran Examples Non Examples terlihat lebih antusias dan lebih aktif dalam mengikuti proses pembelajaran berlangsung. Peneliti memberi rangsangan dengan memberikan gambar-gambar yang berhubungan dengan 
relasi dan fungsi yang ditampilkan dengan OHP. Peneliti memberi permasalahan yang harus diselesaikan oleh masing-masing kelompok, pada proses ini siswa diharapkan saling bertukar pikiran atau saling bekerjasama untuk menyelesaikan permasalahan yang diberikan. Siswa berusaha menemukan penyelesaian dari permasalahan yang diberikan guru dengan diskusi kelompok. Dalam beberapa kesempatan, siswa juga mengajukan pertanyaan-pertanyaan terkait dengan materi yang dianggap sulit untuk dipahami dengan kegiatan ini dapat dimanfaatkan untuk mencoba menyelesaikan permasalahan dengan bantuan teman satu kelompok.

Peneliti ini menggunakan test soal uraian sebanyak 5 (lima) soal sebagai test untuk mencari kemampuan berpikir kritis siswa. Berdasarkan uji hipotesis test awal atau pretest kemampuan berpikir kritis siswa pada materi relasi dan fungsi dapat dilihat bahwa thitung $\geq$ tabel $=0,510$ ini berarti pada taraf signifikan $\alpha$ $=0,05 \mathrm{Ha}$ diterima dan menolak Ho. Sehingga hasil hipotesis memberikan temuan bahwa terdapat pengaruh model pembelajaran Examples Non Examples terhadap kemampuan berpikir kritis siswa di kelas X Akuntansi SMK Az-Zahra Sonomartani.

Dari hasil perhitungan $\mathrm{N}$-gain score tersebut menunjukkan bahwa nilai rata-rata $\mathrm{N}$-gain score untuk metode pembelajaran Examples Non Examples sebesar 62,6187 atau 62,62 \% termasuk dalam kategori cukup efektif. Maka dapat disimpulkan bahwa penggunaan model Examples Non Examples cukup efektif dalam meningkatkan berpikir kritis siswa kelas X Akuntansi di SMK Az-Zahra Sonomartani.

\section{Kesimpulan}

Berdasarkan permasalahan, tujuan penelitian, hasil dan pembahasan penelitian yang telah dipaparkan, maka dapat dirincikan sebagai berikut:

1. Dari penelitian di atas dapat di ketahui bahwa model pembelajaran Examples Non Examples dapat meningkatkan kemapuan berfikir kritis siswa dalam pembelajaran matematika pada kelas $X$ Akuntansi di SMK Swasta Az-Zahra Sonomartani dengan di nilai rata-rata siswa yang diajarkan dengan menggunakan model pembelajaran examples non examples lebih tinggi dibandingkan nilai rata-rata siswa sebelum menggunakan model pembelajaran examples non examples yaitu 57,30 dibandingkan 83,55 . Nilai tertinggi yang diperoleh siswa sebelum menggunakan model pembelajaran examples non examples 75.Nilai tertinggi yang diperoleh siswa setelah menggunakan model pembelajaran examples non examples 95. Berdasarkan uji normalitas dengan menggunakan SPSS Statistik 17.0 dapat terlihat nilai signifikan (2-tiled) 0,051 dinyatakan normal karena lebih besar dari 0,05. Berdasarkan hasil uji t dengan menggunakan SPSS 17.30 diketahui nilai signifikan $0,0510>\alpha=0,05$ sehingga Ha diterima dan menolak Ho. Berarti terdapat pengaruh model pembelajaran examples non examples terhadap kemampuan berpikir kritis siswa dikelas X Akuntansi SMK Az-Zahra Sonomartani.

2. Dari hasil perhitungan uji N-Gain Score tersebut, menunjukan bahwa nilai rata-rata N-gain score untuk metoda pembelajaran Examples Non Examples sebesar 62,6187 atau 62,61 \% termasuk dalam kategori cukupefektif. Maka dapat di simpulkan bahwa penggunaan model pembelajaran Examples Non Examples cukup efektif dalam meningkatkan berfikir kritis siswa kelas X Akuntansi di SMK Swasta Az-Zahra Sonomartani

\section{Daftar Pustaka}

1] Abdurrahman, Mulyono. (2009). Pendidikan Bagi Anak Berkesulitan Belajar. Jakarta: Rineka Cipta..

[2] Ali, Muhammad. (2013). Statistik Penelitian Pendidikan. Yogyakarta: Patama Publishing..

[3] Amri, Sofan. (2013). Pengembangan \& Model Pembelajaran dalam Kurikulum 2013. Jakarta: PT Prestasi Pustaka Publisher.

[4] Arikounto, Suharismi. (2007). Dasar-dasar Evaluasi Pendidikan. Jakarta : Bumi Aksara..

[5] Asrul,dkk. (2014). Evaluasi Pembelajaran. Bandung : Citapustaka Media.

[6] Astuti ( 2018), "Pengaruh Penerapan Model Kooperatif Tipe Number Head Together (NHT) Terhadap Hasil belajar Matematika Siswa Kelas X SMP Negeri 1 Bangkinang", diakses pada (http://ejournal.stkippgri sumbar.ac.id/index.php/jurnal-lemma/article/view/1902/pdf) tanggal 7 Februari 2018, 14.05 WIB.

[7] Bahri, Syaiful. (2013). Strategi Belajar Mengajar. Jakarta: PT Rineka Cipta. 
Hal : $85-92$

[8] Irmayanti, I. (2019). Pengaruh Kemampuan Berpikir Kritis Siswa yang Diajarkan dengan Model Pembelajaran Example Non Example di SMP Negeri 1 NA. IX-X pada Tahun Ajaran 2017/2018. JURNAL PEMBELAJARAN DAN MATEMATIKA SIGMA (JPMS), 5(1), 16-20.

[9] Jaya, Indra. (2010). Statistik Penelitian Untuk Pendidikan. Medan: Cita Pusaka. Kementerian Pendidikan dan Kebudayaan, (2017),http://kemdikbud.go.id/ main/files/download/9c7fdf36a39328d

[10] Rasyidin, Al dan Wahyuddin Nur Nasution. (2011). Teori Belajar dan Pembelajaran. Medan: Perdana Publishing. 